\title{
Socioeconomic impact of rice-cum-fish culture in a selected areas of Bangladesh
}

\author{
M. A. Rahman ${ }^{1}$, S. Haque ${ }^{2}$ and P. K. Sarma ${ }^{3}$ \\ ${ }^{1}$ Department of Agricultural Finance, ${ }^{2}$ Department of Agricultural Economics and ${ }^{3}$ Bangladesh Agricultural University \\ Research System (BAURES), Bangladesh Agricultural University, Mymensingh-2202, Bangladesh
}

\begin{abstract}
The study examines the impact of the rice-cum-fish culture and the rice-mono culture on the rural households at Muktaghachha upazila of Mymensingh district in Bangladesh. Data were collected from 100 farmers of five villages following stratified random sampling technique. Activity budgets were prepared and comparisons were made through the tabular and statistical analyses. Both the rice-cum-fish culture and the rice-mono culture were profitable business for the farmers. However, farmers earned about 3 times higher profits from the rice-cum-fish culture than the ricemono culture. Per hectare net returns of the rice-cum-fish culture and the rice-mono culture were Tk. 15345.00 and 5389.50, respectively. Rice yield, fish consumption, total cost were increased by $11.4,14.5$ and 48.9 percent respectively while human labour employment was increased by 9.4 percent in the integrated rice-cum-fish culture compared to the rice-mono culture. The study clearly hints that the rice-cum-fish culture provides greater scope for higher returns and employment opportunities of human labour than the rice-mono culture.
\end{abstract}

Keywords: Rice-cum-fish culture, Rice mono culture, Socio-economic impact

\section{Introduction}

Bangladesh is one of the developing countries in the world. Rice and fish are the staple foods in Bangladesh. Given the security of land and the need to meet the demand of the increasing population, alleviating poverty and malnutrition, there is no alternative to the rice-cum-fish culture (Gupta et al. 1997). Fish is the main source of animal protein, providing an average $8.4 \mathrm{gm}$ per day, or $13.3 \%$ of the average per capita total intake of protein (63 gm) (BBS, 2010). Not only the adequate supply of carbohydrate, but also the supply of animal protein is significant through rice-fish farming. Fish, particularly small fish, are rich in micronutrients and vitamins, and thus human nutrition can be greatly improved through fish consumption (Larsen et al. 2000; and Roos et al. 2003).

Integration of fish with rice farming improves diversification, intensification, productivity, profitability, and sustainability (Ahmed et al. 2007; and Nhan et al. 2007). It can optimize resource utilization through the complementary use of land and water (Frei and Becker, 2005). It is suggested that integrated rice-fish farming is ecologically sound because fish improve soil fertility by increasing the availability of nitrogen and phosphorus (Giap et al. 2005; and Dugan et al. 2006). The natural aggregation of fish in rice fields inspired the combination of rice farming with fish to increase productivity (Gurung and Wagle, 2005). It is found in several studies that rice-cum-fish culture become able to enhance net benefit by $64.4 \%$ and yield by 5\% ( Purba, 1998). So, it has been proved that the rice -fish integration is quite attractive both in environmental and economic points of view. Though several researchers attempted to study environmental and biological outputs of rice-cum-fish culture, studies on economic output is scant. So, the researchers attempted to undertake the study with the following objectives:

i. to assess the relative profitability of using rice-cum-fish culture compare to rice monoculture;

ii. to determine the effects of the rice-cum-fish culture in changing yields, total costs, fish consumption and labour employment as compared to the monoculture and;

iii. to identify the major problems in conducting integrated rice-fish farming. 


\section{Materials and Methods}

In this study, 100 farmers who adopted both the rice-cum-fish culture and the rice- mono-culture were randomly selected from five villages namely Goshbari, Satrasia, Rajpur, Kumargata, and Kandapara of Muktagachha Upazila in Mymensingh. The period covered in this study was the whole production of the rice-cum-fish culture and the rice-mono-culture in the boro season of 2009. The required data were collected during the March to May, 2009. A stratified random sampling technique was followed in this study. Survey method was used to collect data and analysis was done to achieve the objectives set for the study. Activity budgets were calculated and statistical comparisons were computed. Multiple regression analysis was used to determine the impact of different independent variables on total household income of the respondents which was specified as:

$Y=a+b_{1} X_{1}+b_{2} X_{2}+b_{3} X_{3}+b_{4} X_{4}+b_{5} X_{5}+b_{6} X_{6}+b_{7} X_{7}+e$

Where, $\quad Y=$ Total annual income of the household

$\mathrm{a}=$ Constant term

$X_{1}=$ Age of the respondent

$X_{2}=$ Number of members in the family

$X_{3}=$ Number of working persons in the family

$\mathrm{X}_{4}=$ Education level of the respondent

$X_{5}=$ Size of the total cultivable land

$\mathrm{X}_{6}=$ Distance of the district headquarter market

$X_{7}=$ Lengths of Katcha road from houses to the nearest highway

$\mathrm{e}=$ Error term

Activity budgets (Dillon and Hardaker, 1993) of the rice-cum-fish culture were prepared using the following algebraic equation:

$$
\begin{aligned}
& \pi_{J}=P_{y j} . Y_{j}+P_{j} \cdot B_{j}-\sum_{i=1}^{n}(P x i . X i)-F C \\
& \text { Where, } \\
& \pi_{\mathrm{J}}=\text { per hectare net return or profit of the jth product }(\mathrm{Tk} / \mathrm{ha}) \text {; } \\
& \mathrm{Y}_{\mathrm{j}}=\text { total quantities of the } \mathrm{j}^{\text {th }} \text { main product per hectare }(\mathrm{kg} / \mathrm{ha}) \text {; } \\
& \mathrm{Py}_{\mathrm{j}}=\text { per unit price of the } \mathrm{j}^{\text {th }} \text { main product }(\mathrm{Tk} / \mathrm{kg}) \text {; } \\
& B_{j}=\text { total quantities of the by product per hectare }(\mathrm{kg} / \mathrm{ha}) \text {; } \\
& \mathrm{Pb}_{\mathrm{j}}=\text { per unit price of the by product }(\mathrm{Tk} / \mathrm{kg}) \text {; } \\
& X_{i}=\text { total quantities of inputs used for producing per hectare product; } \\
& \mathrm{Px}_{\mathrm{i}}=\text { per unit price of the } \mathrm{i}^{\mathrm{t} \text { in }} \text { inputs; } \\
& \mathrm{FC}=\text { amount of fixed cost per hectare involved in producing the products; } \\
& \mathrm{j}=1 \text { and } 2 \text { (Rice and Fish) } \\
& i=1,2,3 \text {...n (i.e., human labour, fertilizers, seed/seedlings, irrigation water, power tiller/draught } \\
& \text { animal, etc.) }
\end{aligned}
$$

Apart from the profitability analysis, undiscounted benefit-cost ratio (BCR) was calculated dividing per hectare gross return by gross cost.

\section{Results and Discussion}

\section{Relative profitability of the rice-cum-fish culture compared to the rice mono culture}

The integrated rice-cum-fish culture (considering home supplied labours were paid) per hectare gross return, gross cost and net return were calculated Tk. 83235.00, 67890.00, and 15345.00, respectively and undiscounted BCR was 1.23. In the case of rice-mono culture, these are appeared to be Tk. 50989.50, $45600.00,5389.50$, and 1.12, respectively. Considering home supplied labours were not paid, the corresponding figures were Tk. 83235.00, 59071.5.00, 24163.5.00, and 1.41 for the integrated rice-cumfish culture and Tk. 50989.50, 38439.00, 12550.50, and 1.33 were for rice-mono culture, (Table 1). 
Table 1. Per hectare profitability of integrated rice-cum-fish culture and rice-mono-culture

\begin{tabular}{|l|c|c|c|c|}
\hline \multirow{2}{*}{ Item } & \multicolumn{2}{|c|}{$\begin{array}{c}\text { Considering home supplied labours } \\
\text { were paid }\end{array}$} & \multicolumn{2}{c|}{$\begin{array}{c}\text { Considering home supplied labours } \\
\text { were not paid }\end{array}$} \\
\cline { 2 - 5 } & $\begin{array}{c}\text { Rice-cum-fish } \\
\text { culture }\end{array}$ & Rice mono culture & $\begin{array}{c}\text { Rice-cum-fish } \\
\text { culture }\end{array}$ & $\begin{array}{c}\text { Rice mono } \\
\text { culture }\end{array}$ \\
\hline Gross return(Tk/ha) & 83235.00 & 50989.50 & 83235.00 & 50989.50 \\
Gross cost(Tk/ha) & 67890.00 & 45600.00 & 59071.50 & 38439.00 \\
Net return(Tk/ha) & 15345.00 & 5389.50 & 24163.50 & 12550.50 \\
BCR( Undiscounted) & 1.23 & 1.12 & 1.41 & 1.33 \\
\hline
\end{tabular}

Source: Field Survey, 2009

\section{Effect of the rice-cum-fish culture technology on households}

Net return, yields of paddy, total cost, fish consumption, and labour employment of per hectare of ricecum-fish culture were Tk.165345.00, 4900 kg, Tk.67890, 245.5 gm/day, and 170.00 man-days, respectively. On the other hand, net return, yields of paddy, total cost, fish consumption, and labour employment of per hectare of rice-mono culture were Tk.5389.50, $4400 \mathrm{~kg}$, Tk.45600.00, $214.40 \mathrm{gm} / \mathrm{day}$, and 155.41 man-days, respectively. Effect of the rice-cum-fish culture on the per hectare net return, yields, total costs, fish consumption and labour employment were (+) 184.72\%, (+) 92.53\%, (+) 11.36\%, (+) 48.88\%, (+) 53.67\%, (+) 14.52\%, and (+) 09.37\%, respectively (Table 2 ).

Table 2. Effect of the rice-cum-fish culture technology on households

\begin{tabular}{|l|c|c|c|}
\hline \multicolumn{1}{|c|}{ Item } & Rice-cum fish culture & $\begin{array}{c}\text { Rice mono } \\
\text { culture }\end{array}$ & Change (\%) \\
\hline Net return (Tk/ha) & 15345.00 & 5389.50 & $(+) 184.7$ \\
Yields (Kg/ha) & 4900.00 & 4400.00 & $(+) 11.4$ \\
Total costs (Tk/ha) & 67890.00 & 45600.00 & $(+) 48.9$ \\
Fish consumption (gm/day/family) & 245.50 & 214.40 & $(+) 14.5$ \\
Labour employment (man-days/ha) & 170.00 & 155.41 & $(+) 09.4$ \\
\hline
\end{tabular}

Source: Field Survey, 2009

The estimated coefficients and related statistics of the multiple regression analysis was done to measure the impact of different, influencing variables on total household income, are summarized in Table 3.

Table 3. Estimated coefficients and related statistics of the multiple linear regression analysis

\begin{tabular}{|l|c|c|}
\hline \multicolumn{1}{|c|}{ Independent variables } & Coefficient & $|\mathrm{t}|$ values \\
\hline Age of the respondent & $-505.00^{\star *}$ & 2.7 \\
Number of members in the family & 2902.00 & 1.5 \\
Number of working persons in the family & 3061.00 & 1.8 \\
Education of the respondent & 1110.00 & 2.1 \\
Size of the total cultivable land & $5216.00^{* *}$ & 4.0 \\
Distance of the district head quarter market & $-12137.00^{\star *}$ & 4.4 \\
Lengths of Katcha road from houses to the & & 4.8 \\
nearest highway & $-10533.00^{* *}$ & \\
$\mathrm{R}^{2}$ & 0.83 & \\
$\mathrm{~F}$ & 67.94 & \\
\hline
\end{tabular}

** Significant at 1 percent level. 
Table 3 shows negative effect of farmer's age on annual income - pointing out that old farmers' income is relatively less than young aged farmers. The reason could be, the elders are less willing to adopt new technology including rice-cum-fish farming. According to Hossain (1989), older farmers are less likely to have contacts with extension agents and are less willing to adopt new practices and modern inputs. Furthermore, younger farmers are likely to have some formal education, and therefore might be more successful in gathering information and understanding new practices, which in turn will improve their technical efficiency. The result also shows that farm size is positively related to annual income which indicates better managerial ability of larger farms. Distance of the district head quarter market and lengths of katcha road from houses to the nearest highway are negatively related to annual income. These two variables are the indicator of infrastructure and the result tells that lack of infrastructural facility reduces respondents' income. There is no suspect about the positive role of infrastructure to increase farm income as well non-farm income. The modern rice producer benefits significantly from better infrastructure; and badly developed infrastructure leads to negative effects on both productivity and income Rahman (2003).

\section{Problems of the rice-cum-fish culture}

Farmers were asked to rank the problems they encountered in culturing fish in the rice fields. Major problems were diseases, high labour demand, unexpected mortalities, high cost in general, and high cost of plot preparation in particular. Eighty seven percent farmers claimed that diseases were a major problem, 69\% farmers identified higher labour requirement a major problem for them and $65 \%$ found unexpected mortalities as a constraint in rice-cum-fish culture. Again, $57 \%$ and $55 \%$ of the respondents mentioned about high cost in general and high cost of plot preparation in particular as problem for running their enterprise.

Table 4. Problems for integrating fish culture with rice farming as ranked by farmers (Percentages are in parentheses)

\begin{tabular}{|l|c|c|c|c|c|}
\hline \multirow{2}{*}{\multicolumn{1}{|c|}{ Problem }} & \multicolumn{5}{|c|}{ No. of times problem was ranked } \\
\cline { 2 - 6 } & First & Second & Third & Fourth & Total $(\mathrm{n}=100)$ \\
\hline Water logging & 07 & 09 & 04 & 06 & $26(26)$ \\
\hline Insufficient water & 05 & 07 & 02 & 02 & $16(16)$ \\
\hline Disease & 21 & 23 & 25 & 18 & $87(87)$ \\
\hline Predators & 00 & 00 & 00 & 02 & $02(02)$ \\
\hline Theft & 00 & 00 & 02 & 04 & $06(06)$ \\
\hline Unexpected mortalities & 18 & 20 & 12 & 15 & $65(65)$ \\
\hline Small stocking size & 00 & 00 & 05 & 06 & $11(11)$ \\
\hline Non availability of seed fish & 00 & 00 & 00 & 03 & $03(03)$ \\
\hline Cannot use pesticide & 00 & 00 & 01 & 02 & $03(03)$ \\
\hline High labour demand & 23 & 16 & 18 & 12 & $69(69)$ \\
\hline High costs in general & 15 & 12 & 14 & 16 & $57(57)$ \\
\hline High cost of plot preparation & 11 & 13 & 17 & 14 & $55(55)$ \\
\hline
\end{tabular}

Source: Field Survey, 2009

\section{Conclusion}

The rice- cum-fish culture is an innovative farming system in which, rice is the main enterprise and fish fingerlings are taken as additional means to secure extra income. Rice-cum- fish culture is not only reducing income poverty of the farmers but also improves the yield of paddy, create employment opportunity, and increase nutrient intake which brings food security for them. The farm-specific variables used to explain income indicate that farmers, who are of young aged, with larger farm size and better infrastructural facility - are able to earn more income. Despite of some problems which are facing in ricecum-fish farming, Proper policy and planning, positive attitude of administrators and extension workers, free access to information/training facilities for the farmers, required size of fingerlings at reasonable prices at the appropriate time will encourage the farmers to practice rice-cum-fish culture largely. 
Rahman et al.

\section{References}

Ahmed, N., Wahab, M. A., and Thilsted, S. H. 2007. Integrated aquaculture-agriculture systems in Bangladesh: potential for sustainable livelihoods and nutritional security of the rural poor. Aquaculture Asia, 12(1), 14-22 pp.

BBS 2010.Statistical Yearbook of Bangladesh: Bangladesh Bureau of Statistics, Ministry of Planning, Dhaka. 404 p.

Dillon, J.L. and Hardaker, J.B. 1993. Farm Management Research for Small Farmer Development: FAO Farm Systems Management Series 06, FAO, Rome.

Dugan, P., Dey, M. M., and Sugunan, V. V. 2006. Fisheries and water productivity in tropical river basins: enhancing food security and livelihoods by managing water for fish. Agricultural Water Management, 80, 262-275 pp.

Frei, M. and Becker, K. 2005. Integrated rice-fish culture: coupled production saves resources. Natural Resources Forum, 29, 135$143 \mathrm{pp}$.

Giap, D. H., Yi, Y., and Lin, C. K. 2005. Effects of different fertilization and feeding regimes on the production of integrated farming of rice and prawn Macrobrachium rosenbergii (De Man). Aquaculture Research, 36, 292-299 pp.

Gupta, M.V., Mazid M.A., Rahman. M.A., and Sollows,J.D.1997. Integrated Agriculture-Aquaculture: A way for food Security for small Farmers and Better Resource Management and Environment. International Symposium on Food Security and Innovation Success and Lessons Learned. University of Hohenheim, Germany.

Gurung, T. B., and Wagle, S. K. 2005. Revisiting underlying ecological principles of rice-fish integrated farming for environmental, economical and social benefits. Our Nature, 3, 1-12 pp.

Hossain, M. 1989. Green Revolution in Bangladesh: Impact on Growth and Distribution of Income. University Press Limited, Dhaka.

Larsen, T., Thilsted, S. H., Kongsbak, K., and Hansen, M. 2000.Whole small fish as a rich calcium source. British Journal of Nutrition, 83, 191-196 pp.

Nhan, D. K., Phong, L. T., Verdegem, M. J. C., Duong, L. T., Bosma, R.H., and Little, D. C. 2007. Integrated freshwater aquaculture, cropland livestock production in the Mekong delta, Vietnam: determinants and the role of the pond. Agricultural Systems, 94, 445-458 pp.

Purba, S. 1998. The Economics of Rice-fish Production system in North Sumatra, Indonesia: An Empirical and Model Analysis. Farming Systems and Resource Economics in the Tropics, Vol.31. Wissenschafverlag, Vauk, Kiel, KG.

Rahman, S. and M. Rahman (2003). Impact of land fragmentation and resource ownership on productivity and efficiency: The case of rice producers in Bangladesh. Journal of Land Use Policy 26 (1): 95-103 pp.

Ray, S.C. 1985. Measurement and Test of Efficiency of Farms in Linear Programming Models: A Study of West Bengal Farms. Oxford Bulletin of Economics and Statistics, 47: 371-386 pp.

Roos, N., Islam, M. M., and Thilsted, S. H. 2003. Small indigenous fish species in Bangladesh: contribution to vitamin A, calcium and iron intakes. Journal of Nutrition, 133, 4021-4026 pp. 